\title{
Good Faith Inquiries Under the Bankruptcy Code: Treating the Symptom, Not the Cause
}

In enacting the Bankruptcy Code (the Code), ${ }^{1}$ Congress deliberately eliminated the old Bankruptcy Act's ${ }^{2}$ requirement that a petition for reorganization be filed in "good faith." statutory change, bankruptcy courts continue to explore the motives of debtors who file voluntary petitions for reorganization. Some courts have characterized this as "an "impressive judicial gloss' " on the Code's statutory filing requirements." While there is little question that bankruptcy courts have the power to fashion a good faith requirement, ${ }^{5}$ an inquiry focusing on the debtor's good

1 Bankruptcy Reform Act of 1978, Pub. L. No. 95-598, 92 Stat. 2549 (codified at 11 U.S.C. $\S \S 101-151,326$ (1982), scattered sections of 28 U.S.C. (1982), and other scattered sections of the U.S. Code), amended by Bankruptcy Amendments and Federal Judgeship Act of 1984, Pub. L. No. 98-353, 1984 U.S. Code CoNG. \& AD. News (98 Stat.) 333.

2 Bankruptcy Act of July 1, 1898, ch. 541, 30 Stat. 544 (codified as amended at 11 U.S.C. $\$ \S 1-1200$ (1976)) (repealed 1978) [hereinafter cited without cross-reference as the Bankruptcy Act].

${ }^{3}$ Chapter X of the Bankruptcy Act contained the requirement of good faith in filing. Bankruptcy Act $\S 141,11$ U.S.C. $\$ 541$ (1976). Although the Code's elimination of this requirement is not discussed expressly in either the House Report, H.R. REP. No. 595, 95th Cong., 1st Sess. (1977), reprinted in 1978 U.S. Code Cong. \& AD. News 5963 [hereinafter cited as House REPoRT], or the Senate Report, S. RBP. No. 989, 95th Cong., 2d Sess. (1978), reprinted in 1978 U.S. Code Cong. \& AD. NEws 5787 [hereinafter cited as Senate REPoRT], the commission established by Congress to propose a reformation of national bankruptcy law specifically recommended removing the good faith requirement, REPORT OF THE CoMmisSion on the Bankruptcy Laws of the United States (pt. 1), H.R. Doc. No. 137, 93d Cong., 1st Sess. 183, 222 n.7 (1973).

- See In re Levinsky, 23 Bankr. 210, 217 (Bankr. E.D.N.Y. 1982) (quoting In re 299 Jack-Hemp Assocs., 20 Bankr. 412, 413 (Bankr. S.D.N.Y. 1982)). Commentators have generally supported the application of a good faith requirement. See, e.g., Di Donato, Good Faith Reorganization Petitions: The Back Door Lets the Stranger In, 16 CoNn. L. Rev. 1 (1983); DiPietro \& Katz, Chapter 11 of the Bankruptcy Code-Use or Abuse?, 57 ConN. B.J. 418 (1983); Gaffney, Bankruptcy Petitions Filed in Bad Faith, 12 U.C.C. L.J. 205 (1980); Ordin, The Good Faith Principle in the Bankruptcy Code: A Case Study, 38 Bus. LAw. 1795 (1983); Note, Good Faith in Chapter Eleven Reorganization, 35 S.C.L. REv. 333 (1984).

s Section 305 of the Code allows the court to dismiss or suspend a case where it would be in "the interests of creditors and the debtor" to do so, or where "there is pending a foreign proceeding." 11 U.S.C. § 305(a) (1982). Section 1334 of title 28 (formerly section 1471 of title 28), which gives the district courts jurisdiction over bankruptcy cases, also allows the district or bankruptcy court to "abstain[] from hearing a particular proceeding arising under title 11 or arising in or related to a case under title 11." 28 U.S.C.A. $\$ 1334$ (c) (West Supp. 1985). A decision by a trial court abstaining under either section 1334 or section 305 is not reviewable on appeal. 11 U.S.C. $\S 305$ (c) (1982). 
faith ignores the cause of the creditor's complaint: either the lack of "adequate protection" ruptcy-an essentially procedural legal forum-to alter the appli-

Most cases involving a good faith inquiry under the Code have been initiated by secured creditors under 11 U.S.C.A. § 362(d) (West 1979 \& Supp. 1985) requesting relief from the automatic stay. See, e.g., Myers v. The Beach Club (In re Beach Club), 22 Bankr. 597, 599 (Bankr. N.D. Cal. 1982); Central Bank v. Zed, Inc. (In re Zed, Inc.), 20 Bankr. 462, 462 (Bankr. N.D. Cal. 1982); Provident Bank v. BBT (In re BBT), 11 Bankr. 224, 227 (Bankr. D. Nev. 1981).

Sections 362(d) and 1112(b) both require a showing of "cause" before relief may be granted. See 11 U.S.C.A. § 362(d)(1) (West 1979 \& Supp. 1985) ("On request of a party in interest . . . the court shall grant relief from the stay ... for cause, including the lack of adequate protection . . . ."); id. § 1112(b) ("[0]n request of a party in interest, . . . the court may convert a case under this chapter to a case under chapter 7 [liquidation] or may dismiss a case under this chapter, . . . for cause . . . ."). The legislative history of both provisions states that the standards for determining "cause" were intentionally left openended. With respect to section 362(d), the definition of "cause" is open-ended in two ways. First, by way of a general statement that " $[t]$ he lack of adequate protection of an interest in property . . . is one cause for relief, but it is not the only cause." HouSE REPORT, supra note 3, at 343, 1978 U.S. Code Cong. \& Ad. NewS at 6300; Senate Report, supra note 3, at 52, 1978 U.S. Code CoNG. \& AD. NEwS at 5838. Second, by way of an open-ended definition of adequate protection itself:

[S]ection [361] specifies . . . means of providing adequate protection. They are neither exclusive nor exhaustive. . . . The section does not specify how value is to be determined, nor . . . when it is to be determined. These matters are left to case-by-case interpretation and development. It is expected that courts will apply the concept in light of the facts of each case and general equitable principles.

House REPORT, supra note 3, at 339, 1978 U.S. Code ConG. \& AD. News at 6295; see also In re Alyucan Interstate Corp., 12 Bankr. 803, 805 (Bankr. D. Utah 1981); 2 ColliER ON BANKRUPTCY § 361.01[1] (L. King 15th ed. 1985).

The legislative history of section $1112(\mathrm{~b})$ also embraces an expansive definition of "cause." See House Report, supra note 3, at 406, 1978 U.S. Code Cong. \& AD. News at 6362 ("[The list in section 1112(b)] is not exhaustive. The court will be able to consider other factors as they arise, and to use its equitable powers to reach an appropriate result in individual cases."); Senate REPoRT, supra note 3, at 117, 1978 U.S. Code Cong. \& AD. NEwS at 5903 (same). Courts have interpreted the "equitable" and "case-by-case" language in the definition of "cause" as an invitation to reinstate the good faith requirement. A similar approach characterizes their view of the sections allowing them to stay their jurisdiction: courts applying section 305 or 28 U.S.C.A. $§ 1334$ (c) (West Supp. 1985) usually do so in combination with other sections of the Code. See, e.g., In re Coram Graphic Arts, 11 Bankr. 641, 643, 645-46 (Bankr. E.D.N.Y. 1981) (\$§ 105, 305, and 1112(b)); In re Victory Constr. Co., 9 Bankr. 549, 559-60 (Bankr. C.D. Cal. 1981) (\$ 362(d) and 28 U.S.C. $\$ 1471$ (1982) (currently 28 U.S.C.A. $§ 1334$ (West Supp. 1985)).

One court based the good faith requirement on section 1129(a)(3). See Connell v. Coastal Cable T.V., Inc. (In re Coastal Cable T.V., Inc.), 709 F.2d 762, 764 (1st Cir. 1983). This approach was also adopted by the court in In re Madison Hotel Assocs., 29 Bankr. 1003, 109-10 (W.D. Wis. 1983), but the decision was reversed for failure to make the "legal distinction between the good faith that is required to confirm a plan under section 1129(a)(3) and the good faith that has been established as a prerequisite to filing a Chapter 11 petition for reorganization." In re Madison Hotel Assocs., 749 F.2d 410, 425 (7th Cir. 1984) (emphasis in original) (citation omitted).

${ }^{6}$ For a discussion of adequate protection, see infra note 59 \& notes $82-97$ and accompanying text. 
cable substantive rules. ${ }^{7}$

Courts created the good faith requirement in cases where creditors raised one of two objections: that the debtor filed the petition "solely" in order to forestall the collection efforts of secured creditors $^{8}$ or that the debtor entity was created immediately prior to the filing of the petition in order to place assets of the party creating the debtor beyond the reach of creditors. ${ }^{9}$ These seemingly unrelated cases are united by a common thread: Despite the fact that the creditor's complaint takes the form of a "good faith" objection, the problem is not the debtor's subjective intent; rather, it is the courts' practice of failing to give secured creditors value equivalent to what they would have received in the absence of a bankruptcy proceeding.

This failure by bankruptcy courts to give secured creditors equivalent value-the "adequate protection" required by the Code $^{10}$-is not limited to those cases addressing the question of the debtor's good faith. ${ }^{11}$ The good faith requirement has never-

7 For a discussion of bankruptcy as a collective proceeding, see infra notes 12-28 and accompanying text.

- See, e.g., North Cent. Dev. Co. v. Landmark Capital Co. (In re Landmark Capital Co.), 27 Bankr. 273, 278-79 (Bankr. D. Ariz. 1983); Ketchikan Lodge No. 1429, Benevolent \& Protective Order of Elks v. Hewitt (In re Hewitt), 16 Bankr. 973, 976 (Bankr. D. Alaska 1982); Yaffe v. Andrews (In re Andrews), 17 Bankr. 515, 518 (Bankr. C.D. Cal. 1982); see also In re Coram Graphic Arts, 11 Bankr. 641, 642 (Bankr. E.D.N.Y. 1981) (dismissing petition sua sponte under $\$ \S 105,305$, and $1112(\mathrm{~b})$ for "unreasonable delay by the debtor that is prejudicial to creditors").

- Commonly, assets are transferred from an individual or partnership to another entity immediately before filing. The courts usually have little difficulty finding bad faith in these cases, with little analysis of whether the transfer even affected the substantive rights of the creditors. See, e.g., Central Bank v. Zed, Inc. (In re Zed, Inc.), 20 Bankr. 462, 463 (Bankr. N.D. Cal. 1982); In re Eden Assocs., 13 Bankr. 578, 579-81, 584-85 (Bankr. S.D.N.Y. 1981); Capital Management Co. v. Alison Corp. (In re Alison Corp.), 9 Bankr. 827, 828 (Bankr. S.D. Cal. 1981); In re Dutch Flat Inv. Co., 6 Bankr. 470, 471 (Bankr. N.D. Cal. 1980). But see, e.g., In re Spenard Ventures, Inc., 18 Bankr. 164, 166-67 (Bankr. D. Alaska 1982) (no bad faith where principal of transferee corporation remained personally liable); Chattanooga Fed. Sav. \& Loan Ass'n v. Northwest Recreational Activities, Inc. (In re Northwest Recreational Activities, Inc.), 4 Bankr. 36, 37, 42 (Bankr. N.D. Ga. 1980) (no bad faith where the rights of the creditors were unaffected by the transfer).

A variation on this theme involves the transfer of property from an entity that is ineligible to file under the Code to an eligible entity. See, e.g., In re 299 Jack-Hemp Assocs., 20 Bankr. 412, 412 (Bankr. S.D.N.Y. 1982); Polkin, Inc. v. Lotus Invs. (In re Lotus Invs.), 16 Bankr. 592, 594-95 (Bankr. S.D. Fla. 1981); In re G-2 Realty Trust, 6 Bankr. 549, 551 (Bankr. D. Mass. 1980); see also In re Dolton Lodge Trust No. 35,188, 22 Bankr. 918, 921 (Bankr. N.D. Ill. 1982) (no transfer of assets but an attempt to file as a joint venture).

1011 U.S.C.A. $\S 361$ (West 1979 \& Supp. 1985).

11 See, e.g., Crocker Nat'l Bank v. American Mariner Indus. (In re American Mariner Indus.), 27 Bankr. 1004, 1009 (Bankr. 9th Cir. 1983), rev'd, 734 F.2d 426 (9th Cir. 1984); General Elec. Mortgage Corp. v. South Village, Inc. (In re South Village, Inc.) 25 Bankr. 
theless been grafted onto the Code without any attempt to demonstrate its consistency with the normative underpinnings of bankruptcy law. This failure to give "good faith" a coherent theoretical framework has had an unfortunate, but not unsurprising, result: the extension of the inquiry to cases where the core issue is whether the debtor belongs in a collective proceeding at all. Here too the malleability of the term "good faith" permits a bankruptcy judge to pursue a motive-based inquiry based on concepts of "equity," and to avoid applying a technical statute in a systematic way.

Part I of this comment describes the creditors' bargain model, a framework that can be used to bring clarity to this confused area of bankruptcy law. Part II then examines the kinds of cases in which the good faith of the debtor has been raised and explores the courts' reasoning in such cases. Part III demonstrates that the need for courts to fashion a good faith doctrine has resulted, not from the bad motives of debtors seeking to abuse the bankruptcy process, but rather from the bankruptcy courts' own practice of failing to grant secured creditors truly adequate protection.

\section{The Creditors' Bargain Model}

The purpose of a bankruptcy proceeding is to sort out the rights of various parties. ${ }^{12}$ But the only rights involved in a corporate bankruptcy proceeding are those of persons having an ownership interest in the debtor. ${ }^{13}$ Any discussion of the "debtor's inter-

987, 990 n.3, 1002 (Bankr. D. Utah 1982); In re Pine Lake Village Apartment Co., 19 Bankr. 819, 824 (Bankr. S.D.N.Y. 1982); In re Nixon Mach. Co., 9 Bankr. 316, 317-18 (Bankr. E.D. Tenn. 1981); Imperial Bank v. El Patio, Ltd. (In re El Patio, Ltd.) 6 Bankr. 518, 522-23 (Bankr. C.D. Cal. 1980); Nimmer, Secured Creditors and the Automatic Stay: Variable Bargain Models of Fairness, 68 Mins. L. Rev. 1, 12 (1983) [hereinafter cited as Nimmer, Secured Creditors]; Nimmer, Real Estate Creditors and the Automatic Stay: A Study in Behavioral Economics, 1983 ARIz. ST. L.J. 281, 285 [hereinafter cited as Nimmer, Real Estate Creditors]; O'Toole, Adequate Protection \& Postpetition Interest in Chapter 11 Proceedings, 56 AM. BANkr. L.J. 251, 263-64 (1982); Comment, Adequate Protection and the Automatic Stay Under the Bankruptcy Code: Easing Restraints on Debtor Reorganization, 131 U. PA. L. REv. 423, 428 \& n.33 (1982).

12 See Jackson, Bankruptcy, Non-Bankruptcy Entitlements, and the Creditors' Bargain, 91 YALE L.J. 857, 857-58 (1982).

1s See id.; see also Baird \& Jackson, Corporate Reorganizations and the Treatment of Diverse Ownership Interests: A Comment on Adequate Protection of Secured Creditors in Bankruptcy, 51 U. CHI. L. REv. 97, 103 (1984). The tendency of courts to encourage reorganizations under chapter 11 demonstrates some judicial concern over the rights of "debtors." See, e.g., In re Bermec Corp., 445 F.2d 367, 369 (2d Cir. 1971) ("We are conscious of the deep concern of the manufacturing secured creditors lest their security depreciate beyond adequate salvage, but we must balance that with the Congressional mandate to encourage attempts at corporate reorganization where there is a reasonable possibility of success."); 
est" in a corporate bankruptcy proceeding misconceives the nature of corporations, which are merely legal fictions. Rather, the only legally cognizable interests in the assets held under the corporate name are those of various kinds of "owners": secured and unsecured creditors, and stockholders. ${ }^{14}$

The basic premise of the creditors' bargain model is that bankruptcy law should mirror the agreement these owners would have reached had they bargained among themselves before the debtor experienced financial difficulties. ${ }^{15}$ Outside a bankruptcy proceeding, an unsecured creditor would have to rely on state law remedies to satisfy its claim in the event of default. An individual creditor's principal legal remedy against a nonpaying debtor under state law is to sue the debtor in state court, obtain a judgment against it, and levy on the debtor's property. ${ }^{16}$ The order in which creditors levy on the property determines the priority of their rights to proceeds from the sale of the assets. ${ }^{17}$ If the debtor is subject to claims far in excess of its assets, creditors who levy first will have their claims satisfied in full, while those who come last will leave empty-handed. Creditors, therefore, closely monitor debtors and bring suits as soon as debtors experience financial difficulties. ${ }^{18}$ Since, outside of bankruptcy, creditors have an incentive to levy on a debtor's assets as soon as possible, a debtor having difficulty meeting its financial obligations might be quickly and unnecessarily dismembered by its creditors.

If all the owners could negotiate before the debtor's financial

International Harvester Co. v. Kleinsasser (In re Kleinsasser), 12 Bankr. 452, 455 (Bankr. D.S.D. 1981) ("[I]t was the intent of Congress . . . that a debtor be given one meaningful opportunity to rehabilitate. . . . [The automatic stay] provides a debtor a breathing spell from his creditors to attempt a reorganization."). Whether the concern is over debtors per se or employees, customers, or trade partners is unclear, but in any event, the practice of encouraging reorganizations is highly questionable from a theoretical viewpoint. See Baird, Corporate Debtors and Bankruptcy Policy, J. LEgal Stud. (forthcoming).

14 See Baird \& Jackson, supra note 13, at 105 \& n.28.

1s See Jackson, supra note 12, at 859-60.

16 D. Baird \& T. Jackson, Cases, Problems, and Materials on Bankruptcy $3-6$ (forthcoming).

${ }^{17}$ This applies to unsecured creditors, who must jump through a number of procedural hoops in order to obtain satisfaction of their claims from the debtor's property. The requirements vary from state to state, but usually involve obtaining a lien on specific property and then levying on that property. See generally D. BAIRo \& T. JAckson, supra note 16, at 6-9; Stefan Riesenreld, Creditors' Remedizs and Debtors' Protrction 94-175 (3d ed. 1979). Secured creditors take security interests in specific assets, the principal advantage of which is the "priority rights" this gives the secured creditor against competing claims to the asset. See generally D. BAIRD \& T. JAcKson, supra note 16, at 14-15; S. RIESENRELD, supra, at 175215.

18 See Jackson, supra note 12 , at 862 . 
condition weakened, creditors would not agree to the piecemeal liquidation of the debtor under state law through a series of individual suits. ${ }^{19}$ Rather, they would contract for a collective proceeding for resolving their claims against the estate. ${ }^{20}$ Such a proceeding would offer three benefits to creditors. First, it would reduce strategic costs because creditors would no longer have to monitor the debtor to preserve their claims. ${ }^{21}$ Second, creditors would benefit from the administrative efficiencies that result from a collective proceeding. Instead of creditors bringing individual suits, all claims against the debtor would be adjudicated in one proceeding, thus lowering the costs each creditor must bear. ${ }^{22}$ Third, and most important, because a collective proceeding results in an increased pool of assets for the satisfaction of the creditors' claims. A firm is often worth more as a gaing concern than it would be if it were liquidated on a piecemeal basis. A collective proceeding allows the creditors to keep the debtor's assets intact if such action would increase their expected total return. ${ }^{23}$

Under the creditors' bargain model, federal bankruptcy law creates a procedural forum that puts the debtor's assets to their most efficient use. A corollary of the procedural nature of bankruptcy is that the substantive rights of the creditors should be changed only to the extent necessary to effectuate the collective proceeding. ${ }^{24}$ While creditors would agree to a proceeding that increased their expected return, they would not agree to a procedure that systematically transferred value from one class of owners to another. Thus, the baseline for a creditor's right inside of bankruptcy is what it would be entitled to have outside of bankruptcy. ${ }^{25}$

19. Id. at $862-64$.

${ }^{20}$ Id. at $860-71$.

${ }^{21}$ Id. at $861-64$.

22 Id. at $866-67$.

${ }^{23}$ Id. at 864-66.

24 See Baird \& Jackson, supra note 13, at 108 n.40.

${ }^{25}$ See Butner v. United States, 440 U.S. 48, 54-56 (1979) (stating that the determination of property rights inside bankruptcy should be governed by state law rather than by "undefined considerations of equity"); Baird \& Jackson, supra note 13, at 103; Eisenberg, Bankruptcy Law in Perspective, 28 UCLA L. REv. 953, 953-59 (1981); Jackson, supra note 12, at 871; cf. Commodity Futures Trading Comm'n v. Weintraub, 105 S. Ct. 1986, 1992 (1985) ("[The proper inquiry is] to consider the roles played by the various actors of a corporation in bankruptcy to determine which is most analogous to the role played ... [in] a solvent corporation [outside of bankruptcy]."); Comment, Waiver of the Attorney-Client Privilege by the Trustee in Bankruptcy, 51 U. CrI. L. Rev. 1230, 1241-46 (1984) (same). But see Bank of Marin v. England, 385 U.S. 99, 103 (1966) ("There is an overriding consideration that equitable principles govern the exercise of bankruptcy jurisdiction."); SEC v. United States Realty \& Improvement Co., 310 U.S. 434, 455 (1940) ("A bankruptcy court is 
It might be thought that the inclusion of secured creditors would alter this theoretical analysis. Because state law guarantees secured creditors at least the value of their security even in the event of piecemeal liquidation, they have no interest in seeing that other creditors receive a larger return. Outside of bankruptcy, the secured creditor has bargained for a right to seize and sell specific assets to satisfy its claim against the debtor. ${ }^{26}$ The secured creditor differs from the general creditor because the secured creditor contracts with the debtor to receive payment from the sale of specific assets if the debtor defaults. ${ }^{27}$ This right is similar to the general creditor's right to be paid in full before shareholders receive any return on their investment. Because the secured creditor is assured that its claim will be satisfied up to the full value of its security, a collective proceeding offers it little, if any, additional benefit. Yet this does not mean that the secured creditor would object to such a proceeding; if the secured creditor were assured that its recovery would not be reduced, it would be indifferent to the imposition of a collective proceeding. And, since general creditors and shareholders would benefit from a collective proceeding, all parties would agree to such a system so long as it assured secured creditors the full value of their claims.

Whether or not secured creditors are in fact entitled to receive the full value of their claims within bankruptcy is the real issue at the core of the good faith problem. The creditors' bargain model suggests that these creditors should receive full value in order to ensure that they have no disincentive to participate in the collective proceeding. ${ }^{28}$ If the bankruptcy process systematically fails to

a court of equity . . . and is guided by equitable doctrines and principles except in so far as they are inconsistent with the Act.") (citations omitted).

28 See generally U.C.C. art. 9 (1978) (governing rights and duties of parties to secured transactions).

${ }^{27}$ See Baird \& Jackson, supra note 13, at 112-14.

2s See Jackson, supra note 12, at 901-06. Professors Baird and Jackson argue that "[w]ithout being disingenuous, one cannot rely on a provision designed to protect secured creditors from undercompensation to justify a policy-such as not protecting the time value of money - that must undercompensate them both in theory and in practice." Baird \& Jackson, supra note 13 , at 129 . They argue that requiring time-value compensation is fair because it makes junior parties pay for the risk of failure where they stand to benefit from the possibility of success, $i d$. at 100-01, 108-10, and assert that time-value compensation will not hinder desirable reorganizations, $i d$. at 100-01, 109-10, 118-19 \& n.68.

Other commentators disagree with this approach on the ground that the bankruptcy process encompasses other goals in addition to sorting out nonbankruptcy entitlements. Professor Nimmer, for example, asserts that giving the secured creditor the time value of money will defeat too many viable reorganizations, in conflict with a congressional policy of encouraging reorganizations over liquidations. See Nimmer, Secured Creditors, supra note 
give secured creditors such value, however, debtors have an incentive to enter bankruptcy in order to forestall collection efforts by secured creditors and thereby gain at the creditors' expense. Secured creditors have a corresponding incentive to keep debtors out of bankruptcy in order to preserve the value of their claims. Thus, although the secured creditors' real worry is that they will not be assured full value in the bankruptcy proceeding, they are forced to cloak this concern in the guise of an attack on the debtor's motive-that is, that it lacked "good faith"-in filing the bankruptcy petition.

\section{Judicial Imposition of a Good Faith Requirement}

The conventional wisdom is that bankruptcy reorganization has two goals: the promotion of a "fresh start" for debtors and the equitable resolution of the claims of creditors. ${ }^{29}$ There is thought to be an inherent tension between these two goals, and the Code is viewed as representing a compromise between the interests of creditors and equity participants. ${ }^{30}$ From this perspective, bank-

11, at 15. Commentators who argue against time-value compensation usually recognize that any other policy results in a transfer of wealth from the secured creditor to the debtor. See, e.g., id. at 9; James \& Kirkland, Adequate Protection Through Augmented Interests in Reorganization Plans, 58 Am. BANkr. L.J. 69, 74 n.27 (1984). Such policies are defended nonetheless, on the ground that bankruptcy should take account of factors extrinsic to the instant dispute between the parties, such as the effect a liquidation might have on employees, the local community, or suppliers. See, e.g., In re Bonded Mailings, Inc., 20 Bankr. 781, 785 (Bankr. E.D.N.Y. 1982) ("To dismiss these proceedings would be to throw the instant debtors to the mercy of the [unsecured creditors'] collection efforts destroying both jobs and any hope of recovery by the debtors' other unsecured creditors . . . ."); Comment, supra note 11, at 427 ("The court should accord weight, not only to the interests of the debtor and creditor, but also to the interest of the debtor's employees in keeping their jobs; that of the public in generating tax revenues and avoiding increased unemployment and welfare payments; that of consumers in maintaining competition in the debtor's industry; and that of the debtor's suppliers in receiving a reasonable return on their unsecured claims.") (footnote omitted).

${ }^{29}$ See, e.g., Edleman v. Gleason (In re Silver Mill Frozen Foods, Inc.) 23 Bankr. 179, 184 (Bankr. W.D. Mich. 1982) ("While one of the purposes of the Bankruptcy Code is to insure a 'fresh start' for debtors, an equally important purpose is to provide for an equitable distribution of the bankrupt's assets among his creditors. . . ."); Capital Management Co. v. Alison Corp. (In re Alison Corp.), 9 Bankr. 827, 829 (Bankr. S.D. Cal. 1981) ("One basic purpose of the Bankruptcy Code remains . . . giving the debtor a 'fresh start.' . . . Another main thrust of the bankruptcy system is . . . equitable . . . distribution to creditors.").

30 The clearest illustration of this supposed tension is in the commentary on adequate protection. See, e.g., Nimmer, Real Estate Creditors, supra note 11, at 284 ("[T]he adequate protection standard mandates a balance between the secured creditor's right to enforce its bargain and the desirability of [the debtor's] retaining property to achieve broader bankruptcy objectives."); Comment, supra note 11, at 426 ("[T] tion' brings the secured creditor's contractual and property rights into direct conflict with the policy favoring debtor rehabilitation ....."). 
ruptcy is often viewed as a struggle between a piteous debtor and the cold, though just, demands of creditors. ${ }^{31}$ Deciding who is entitled to what is considered so difficult that bankruptcy law has had an unfortunate tendency to fudge the answers. ${ }^{32}$

The creditors' bargain model implies that the goal of promoting a debtor's fresh start is meaningless where that debtor is a corporation. The "owners" of a corporation include its creditors, and they are indifferent to the corporation's continued existence. Their goal is to obtain the best return on their investment, and a decision to reorganize implies only that there is a greater expected value in the corporation's continued existence than in its immediate liquidation. ${ }^{33}$ Yet this model does not describe how judges decide cases. This section of the comment will examine what bankruptcy judges have actually done and will explain how the good faith inquiry conceals a fundamental failure to understand the requirements of the Code.

The cases fall into three general categories: those involving transfers of assets to the debtor near the time of the filing of the petition; those raising the issue of the feasibility of reorganization and, implicitly, the issue of adequate protection; and those in which an inquiry into motive masks the basic question of whether the owners will benefit from a collective proceeding.

31 See Murphy, Restraint and Reimbursement: The Secured Creditor in Reorganization and Arrangement Proceedings, 30 Bus. Law. 15, 16 (1974) ("To a large extent, case law concerning the restraint of creditors in bankruptcy proceedings has been shaped in ... cases where the dry property rights of the creditor must be balanced against very human concerns ..... It is hardly surprising that the equities are usually balanced against the secured creditor.").

${ }^{32}$ One area where the "tendency to fudge" is repeatedly demonstrated is in the valuation of collateral. See infra notes 94-95 and accompanying text. Another illustration was the uncertainty of the standards provided under the old Bankruptcy Act for determining which chapter provided the appropriate proceeding for a given debtor. See House REPORT, supra note 3, at 223, 1978 U.S. CODE CoNG. \& AD. News at 6182-83 ("The establishment of the two chapters [governing corporate reorganizations was due in large part] to the inability of Congress or the bankruptcy community, both the bar and academia, to decide what it was that creditors were ultimately entitled to receive: liquidation or going-concern value. They finessed the issue by the adoption of two chapters."). A third case in point is the treatment of the legislative history of the Code's standard of adequate protection. Requiring time-value compensation for secured creditors is consistent with that legislative history and with a theoretical understanding of the proper role of bankruptcy; the legislative history, however, contains enough open-ended language emphasizing the need to "do equity" that one may be led to conclude that time-value compensation is not required. See infra note 87.

ss See Baird \& Jackson, supra note 13, at 109 ("[A] firm should be kept intact only if it has more value as a going concern than liquidated, because only then will the assets be put to their highest-valued use."). 
A. Transfers of Assets Immediately Prior to Filing the Petition

A substantial number of good faith cases involve creditors who challenge bankruptcy petitions because of last-minute asset transfers to the debtor. These cases generally follow one of two patterns. An example of the first would occur where the trustees of a testamentary trust wish to file a petition for bankruptcy on behalf of the trust. Under the Code, a bankruptcy court could not entertain such a petition because nonbusiness trusts are ineligible for a bankruptcy proceeding. ${ }^{34}$ Unable to file a petition, the trustees transfer all of the trust's assets and liabilities to a corporation. The corporation immediately files a bankruptcy petition, and the trust's secured creditors file a complaint seeking dismissal of the petition as one that was filed in bad faith. ${ }^{36}$

An example of the second pattern would occur where an individual, who owns a number of assets, faces a foreclosure proceeding on one of them. He could file a bankruptcy petition on his own behalf, subjecting all his assets to a bankruptcy proceeding and perhaps to the control of a trustee; ${ }^{36}$ the automatic stay ${ }^{37}$ provision would then prevent foreclosure. In the alternative, the individual can create a new corporation, transfer the asset subject to foreclosure to the corporation, and immediately cause the corporation to file a bankruptcy petition. This process also prevents the secured creditor from foreclosing on the asset, but without subjecting all of the individual's other assets to a bankruptcy proceeding. If the debtor chooses this second option, the secured creditor who initi-

34 Nonbusiness trusts are excluded from the definition of "person" under the Code, 11 U.S.C.A. § 101(33) (West Supp. 1985) ("'person' includes individual, partnership, and corporation"); $i d$. $\$ 101(8)$ (defining a "corporation" as including only business trusts), and "only a person . . . may be a debtor" under the Code, id. § 109(a).

${ }^{35}$ Cases falling within this pattern include In re 299 Jack-Hemp Assocs., 20 Bankr. 412, 412-14 (Bankr. S.D.N.Y. 1982) (transfer of property from a probate estate); Polkin, Inc. v. Lotus Invs. (In re Lotus Invs.), 16 Bankr. 592, 594-95 (Bankr. S.D. Fla. 1981) (transfer from an ineligible trust to a corporation); In re G-2 Realty Trust, 6 Bankr. 549, 550-53 (Bankr. D. Mass. 1980) (transfer from an ineligible nominee trust to an eligible business trust); see also In re Dolton Lodge Trust No. 35,188, 22 Bankr. 918, 921 (Bankr. N.D. Ill. 1982) (no transfer of assets but an attempt to file as a joint venture). But cf. In re Ponn Realty Trust, 4 Bankr. 226, 229-31 (Bankr. D. Mass. 1980) (analysis turns on the permissible uses of chapter 13 and chapter 11: "under the proper circumstances, a business trust such as a realty trust with transferrable [sic] shares may be a proper debtor under Chapter 11").

ss 11 U.S.C.A. §§ 1104, 1302 (West 1979 \& Supp. 1985). The filing of a petition for bankruptcy creates an "estate," which includes "all legal or equitable interests of the debtor in property." Id. $\S 541(\mathrm{a})(1)$. Section 363 of the Code limits the use, sale, and lease of the property in the estate by the trustee. Id. $\$ 363$.

${ }^{37}$ Id. $\S 362$. 
ated the foreclosure proceeding may petition the bankruptcy court to dismiss the corporation's petition as being filed in bad faith. ${ }^{38}$

Most bankruptcy courts attempt to handle such situations through an inquiry into the debtor's good faith. Ordinarily, however, they offer no justification for the inquiry; instead, they merely assert that the inquiry should be undertaken, ${ }^{39}$ even though the good faith requirement for the filing of a petition is not expressed in the Code itself. ${ }^{40}$ One attempt at a justification was offered by the court in In re Victory Construction Co. ${ }^{11}$ The court began its analysis by describing the long history of good faith inquiries in bankruptcy and concluded that, in light of this tradition, "[i]t would be more than anomalous to conclude that . . . Congress [in eliminating the Act's good faith requirement] intended to do away with a safeguard against abuse and misuse of process which had been established and accepted as part of bankruptcy philosophy ... for almost a century."42

3s Cases falling under this pattern include Meadowbrook Investors v. Thirtieth Place, Inc. (In re Thirtieth Place, Inc.), 30 Bankr. 503, 504-06 (Bankr. 9th Cir. 1983) (applying a clearly erroneous standard of review to what it characterized as the "factual issue" of whether the debtor "was created for the predominant purpose of filing in bankruptcy" and reversing the lower court's determination that the debtor filed in good faith); In re FJD, Inc., 24 Bankr. 138, 139-41 (Bankr. D. Nev. 1982) (finding lack of good faith in debtor's transfer of personal residence to a corporation that conducted no business operations while debtor maintained other property out of corporate solution); Central Bank v. Zed, Inc. (In re Zed, Inc.), 20 Bankr. 462, 463-64 (Bankr. N.D. Cal. 1982) (concluding that the purpose of the transfer was to protect the debtor's other assets, without making clear what guarantees or recourse were available prior to transfer); In re Eden Assocs., 13 Bankr. 578, 579-81, 58485 (Bankr. S.D.N.Y. 1981) (motion by the debtor to set aside creditor foreclosure sale denied on a theory of equitable estoppel overlaid by a discussion of the debtor's bad faith in having conducted a series of unrecorded transfers); Capital Management Co. v. Alison Corp. (In re Alison Corp.), 9 Bankr. 827, 828 (Bankr. S.D. Cal. 1981) (transfer to corporation in order to protect individual owner's other assets); In re Dutch Flat Inv. Co., 6 Bankr. 470, 471 (Bankr. N.D. Cal. 1980) (transfer of property in order to avoid submitting the assets of the corporation's "parent entities").

30 Courts have characterized the nature of this inquiry in several ways, but the one that is most often relied upon first appeared in Chattanooga Fed. Sav. \& Loan Assoc. v. Northwest Recreational Activities, Inc. (In re Northwest Recreational Activities, Inc.), 4 Bankr. 36, 39 (Bankr. N.D. Ga. 1980): "Good faith . . . is merged into the power of the court to protect its jurisdictional integrity from schemes of improper petitioners seeking to circumvent jurisdictional restrictions and from petitioners with demonstrable frivolous purposes absent any economic reality." The justification for the doctrine has not been developed much further than this. Indeed, in Central Bank v. Zed, Inc. (In re Zed, Inc.), 20 Bankr. 462, 463-64 (Bankr. N.D. Cal. 1982), the court offered no justification at all for the inquiry, and merely made identical statements under "Findings of Fact" and "Conclusions of Law" that "[t]he Chapter 11 case was not filed in good faith."

40 See supra note 3 and accompanying text.

19 Bankr. 549 (Bankr. C.D. Cal. 1981).

12 Id. at 558. 
The court analyzed the purposes underlying the bankruptcy mechanism, noting correctly that bankruptcy proceedings are a method of preserving the going concern value of the debtor. ${ }^{43}$ The court went further, however, and asserted somewhat nebulously that there are those who wish to use bankruptcy for illegitimate ends. ${ }^{44}$ Although the court did not explain how one should determine what ends were illegitimate nor why they should be considered so, it did observe that the good faith and bad faith uses of bankruptcy met at a borderline, a "borderline ... patrolled by courts. of equity armed with the doctrine of 'good faith." "45

In these borderline cases, what passes for analysis of a debtor's good faith is usually no more than a conclusion. This is well illustrated by the opinion in In re G-2 Realty Trust. ${ }^{46}$ In that case, a secured creditor gave G-2 Realty, a Massachusetts nominee trust, a construction loan in return for a mortgage and security interest in a building leased and owned by G-2 Realty. ${ }^{47}$ The secured creditor also received an assignment of the rents from the building as security for the loan. ${ }^{48}$ When G-2 Realty defaulted on its payments, the secured creditor began collecting rents directly from tenants, took possession of the property, and initiated foreclosure proceedings. ${ }^{49}$ The beneficiaries of the trust, understanding that a nominee trust is not a debtor eligible for bankruptcy under the Code, amended G-2 Realty's declaration of trust to transform G-2 Realty from a nominee trust to an eligible business trust. ${ }^{50}$ G-2 Realty then filed a bankruptcy petition, and the secured creditor brought an action in the bankruptcy court alleging that the petition was

13 Id.

14 Id.

45 Id. (footnote omitted). In Victory, the court in fact hinted that adequate protection was the underlying problem in transfer-of-asset cases. Noting that cases questioning the good faith of debtor filings often were instigated by "entities whose financial interests were threatened by the delay and expense associated with a [bankruptcy proceeding]," $i d$., the court implied that at least one cause of good faith challenges was the failure to give parties to a proceeding value equivalent to what they would have received outside bankruptcy. In the case of secured creditors, the time value of money must be included before protection can be deemed adequate. See infra notes 82-97 and accompanying text. The Victory court, however, fell back on notions of equity in dismissing the petition "independent of the existence or lack of adequate protection." 9 Bankr. at 560. Behind this holding was the debtor's attempt to use reorganization as "a vehicle for profit through use of the secured creditors" collateral at low interest not currently available in the real estate market[]," id. at 565, a situation that could easily have been remedied by providing time-value compensation.

46 Bankr. 549 (Bankr. D. Mass. 1980).

4 Id. at 550 .

$48 I d$.

48 Id.

so Id. at 550-51. 
filed in bad faith. ${ }^{51}$ In resolving the dispute the court stated:

[A]n alteration in legal form solely to become eligible as a debtor under the Code is not, standing alone, sufficient to require a finding of bad faith. . . . Nevertheless, when such a transformation occurs at or near the time a petition is filed, it is a significant factor .... [T] [he Court must satisfy itself that the debtor demonstrates "exemplary motives and scrupulous good faith" before allowing the debtor to obtain the benefits available under Chapter $11 .^{\mathrm{62}}$

The court then dismissed the petition, accepting the secured creditor's argument that the change in the debtor's form "was accomplished not for any legitimate business purpose, but rather to delay the foreclosure sale and to prevent the [secured creditor] from exercising its lawful rights."

This inquiry into the debtor's intent is the typical form that good faith analysis takes, ${ }^{54}$ and G-2 Realty shows how pointless it can be. The good faith inquiry was not based on any interpretation of the statutory provision at issue. No attempt was made to explain why the intent of the parties was relevant to resolving the central questions of how the former nominee trust failed to fit into the permissible business trust form. No effort was made to determine whether adequate protection was available to compensate the secured creditor for foregoing its right to foreclosure. Rather, the good faith inquiry seems to have been based on a visceral reaction to certain types of behavior. In fact, the behavior that courts find distasteful results from infirmities in their own application of bankruptcy rules. Good faith inquiries paper over these difficulties

\footnotetext{
si Id.

${ }^{32}$ Id. at 553-54 (citations omitted).

ss Id. at 551 .
}

Bt This is usually couched in terms of an inquiry into whether the "sole purpose" of the debtor was to delay creditors. See, e.g., Meadowbrook Investors v. Thirtieth Place, Inc. (In re Thirtieth Place, Inc.), 30 Bankr. 503, 505-06 (Bankr. 9th Cir. 1983); R \& M Porter Farms, Inc. v. Green Hills Prod. Credit Assoc. (In re R \& M Porter Farms, Inc.), 38 Bankr. 88, 91 (Bankr. W.D. Mo. 1984); North Cent. Dev. Co. v. Landmark Capital Co. (In re Landmark Capital Co.), 27 Bankr. 273, 279 (Bankr. D. Ariz. 1983); In re FJD, Inc., 24 Bankr. 138, 141 (Bankr. D. Nev. 1982); In re Mogul, 17 Bankr. 680, 681 (Bankr. M.D. Fla. 1982); In re Coram Graphic Arts, 11 Bankr. 641, 642 (Bankr. E.D.N.Y. 1981); Provident Bank v. BBT (In re BBT), 11 Bankr. 224, 235 (Bankr. D. Nev. 1981); Capital Management Co. v. Alison Corp. (In re Alison Corp.), 9 Bankr. 827, 829-30 (Bankr. S.D. Cal. 1981); In re Victory Constr. Co., 9 Bankr. 549, 564-65 (Bankr. C.D. Cal. 1981); In re Dutch Flat Inv. Co., 6 Bankr. 470, 471 (Bankr. N.D. Cal. 1980); In re Fast Food Properties, Ltd., 5 Bankr. 539, 540 (Bankr. C.D. Cal. 1980). 
by resolving disputes without addressing the underlying problem. ${ }^{55}$

\section{B. Feasibility of Reorganization and the Issue of Adequate Protection}

Courts have also used the good faith inquiry when a secured creditor raises the issue of the feasibility of reorganization and the related problem of adequate protection. To illustrate, assume that a corporation's sole asset is a piece of real estate that has a present market value of $\$ 10,000$. The corporation purchased this real estate three years ago with a $\$ 10,000$ loan from a bank. The real estate secures the bank's loan, which has a six-percent contract rate of interest, as compared with the present twelve-percent market rate. During the past three months the corporation has fallen behind on its payments to the bank, and the bank, anxious to reinvest its funds at the present rate of interest, initiates a foreclosure proceeding on the real estate. The corporation responds by filing a bankruptcy petition seeking a reorganization under chapter 11 of the Code; this prevents the bank from foreclosing on the collateral because of the Code's automatic stay provision. ${ }^{56}$ The bank makes a motion in the bankruptcy court for relief from the automatic stay on the grounds that reorganization is infeasible, it is not receiving the adequate protection mandated by the Code, and the petition was filed solely as a bad faith attempt to forestall the foreclosure. ${ }^{.7}$

Courts implementing the adequate protection requirement have often held that where the value of the collateral is stable, the secured creditor is not entitled to receive anything further, or that where the secured creditor is oversecured, payments at the con-

${ }^{68}$ In G-2 Realty, as in Victory, the problem underlying the good faith challenge was one of adequate protection. As the court noted, the change of form from a nominee trust, ineligible for bankruptcy under the Code, to an eligible business trust could "delay or prevent the imminent foreclosure sale [of the secured party]." G-2 Realty, 6 Bankr. at 554. The only reason that delay could have been disadvantageous to the secured lender in G-2 Realty is that the secured party was not receiving the time value of money. By deciding the case under the good faith analysis, the court avoided addressing this important bankruptcy issue. Further, in determining whether the secured party is receiving adequate protection, the debtor's motives for filing the petition are simply irrelevant. Yet, the good faith approach relies on precisely this factor in resolving the dispute.

so 11 U.S.C.A. § 362 (West 1979 \& Supp. 1985).

s7 See, e.g., In re Madison Hotel Assocs., 29 Bankr. 1003, 1010 (W.D. Wis. 1983), rev'd, 749 F.2d 410 (7th Cir. 1984); North Cent. Dev. Co. v. Landmark Capital Co. (In re Landmark Capital Co.), 27 Bankr. 273, 276-77 (Bankr. D. Ariz. 1983); Yaffe v. Andrews (In re Andrews), 17 Bankr. 515, 518 (Bankr. C.D. Cal. 1982); Ketchikan Lodge No. 1429, Benevolent \& Protective Order of Elks v. Hewitt (In re Hewitt), 16 Bankr. 973, 976 (Bankr. D. Alaska 1982); Provident Bank v. BBT (In re BBT), 11 Bankr. 224, 228 (Bankr. D. Nev. 1981). 
tract rate of interest under the authority of section $506(b)^{58}$ are sufficient. ${ }^{39}$ Where the contract rate is less than the prevailing market rate of interest, debtors have filed petitions to take advantage of this favorable bankruptcy treatment, and courts have responded by analyzing the cases under the good faith doctrine to determine whether the "sole purpose" for filing was to preserve the low interest loan. ${ }^{60}$ But this intent-based inquiry glosses over the more important question of precisely what should constitute adequate protection. It also fails to recognize that improper motives are in fact caused by the courts' improper definition of adequate protection.

The analysis of the court in Provident Bank v. BBT (In re $B B T)^{61}$ illustrates these problems. In $B B T$, the debtor leased boxcars, a substantial number of which were collateral for secured loans. After a sudden, dramatic drop in the demand for its boxcars and ensuing financial difficulty, the debtor filed a petition for reorganization. The secured creditor, who was undersecured for the amount of its loan to the debtor, challenged the good faith of the petition, presumably fearing that the amount of its recovery was likely to decrease in a bankruptcy proceeding. The court viewed the secured creditor's complaint as a straightforward attack on the

s8 11 U.S.C.A. § 506(b) (West 1979 \& Supp. 1985).

s9 This is often characterized as protection arising out of the debtor's "equity cushion." See, e.g., In re Pine Lake Village Apartment Co., 19 Bankr. 819, 823-28 (Bankr. S.D.N.Y. 1982); Cable Sys., Inc. v. Coors of the Cumberland, Inc. (In re Coors of the Cumberland, Inc.), 19 Bankr. 313, 321 (Bankr. M.D. Tenn. 1982); Worcester County Nat'l Bank v. Xinde Int'l, Inc. (In re Xinde Int'l, Inc.), 13 Bankr. 212, 215-16 (Bankr. D. Mass. 1981); Crocker Nat'l Bank v. American Mariner Indus. (In re American Mariner Indus.), 10 Bankr. 711, 712-13 (Bankr. C.D. Cal. 1981), aff'd, 27 Bankr. 1004 (Bankr. 9th Cir. 1983), rev'd, 734 F.2d 426 (9th Cir. 1984); But see Bankers Life Ins. Co. v. Alyucan Interstate Corp. (In re Alyucan Interstate Corp.), 12 Bankr. 803, 809-12 (Bankr. D. Utah 1981) (generally critical of the equity-cushion analysis while endorsing a somewhat looser fact-based framework more solicitous of the debtor's need for the property in its reorganization). In a variation on this theme, some courts seek to preserve either the bargained-for debt/equity ratio at the initiation of the loan transaction or a ratio commensurate with commercial realities. See, e.g., Ingersoll-Rand Fin. Corp. v. 5-Leaf Clover Corp. (In re 5-Leaf Clover Corp.), 6 Bankr. 463, 466-68 (Bankr. S.D.W. Va. 1980) (requiring payments at the contractual rate and on the rate of depreciation of the collateral so as to preserve the equity cushion necessary to allow the creditor a commercially reasonable time in which to dispose of seized property without loss); Diversified Mortgage Investors v. Lake Tahoe Land Co. (In re Lake Tahoe Land Co.), 5 Bankr. 34, 37 (Bankr. D. Nev. 1980) (requiring equity cushion of $40-50 \%$ as commercially reasonable for undeveloped land).

so See, e.g., Yaffe v. Andrews (In re Andrews), 17 Bankr. 515, 519 (Bankr. C.D. Cal. 1982) (dismissal for bad faith where the court concluded that the debtor's primary purpose was to take advantage of the contract's $6 \%$ interest rate when the current market rate was $18 \%$ ); In re Victory Constr. Co., 9 Bankr. 549, 564 (Bankr. C.D. Cal. 1981) (similar).

111 Bankr. 224 (Bankr. D. Nev. 1981). 
feasibility of the reorganization and denied the motion to vacate the stay. ${ }^{62}$ Its decision not to lift the automatic stay was based on the view that "where the value of the collateral is firm, the secured creditor is adequately protected ... [so long as] the collateral is ... properly insured, relieved of taxes, and properly maintained." the dicta of the court in Victory that the resolution of the good faith issue is independent of the presence or absence of adequate protection. ${ }^{64}$ The court did not, however, explain why the good faith issue should have arisen at all if there was adequate protection.

In Yaffe v. Andrews (In re Andrews), ${ }^{65}$ the debtor held an interest in a beachfront home that secured a loan with an interest rate that was quite low in light of current market conditions. ${ }^{66}$ The court dismissed the petition for reorganization, on the ground that it was filed primarily to preserve the low interest rate: "Accordingly, it is not a proceeding within the contemplation, intent, or purpose of Chapter 11 of the Code ... [because the debtor did not file with] that candor, frankness, sincerity, and willingness to do equity which are the indicia of 'good faith." "67 Despite the fact that it appeared that the debtor could have provided adequate protection in the form of payments at the current market rate of interest, $^{68}$ the court did not consider the possibility of ordering it to do so. It also completely ignored the relationship between the good faith issue and the question of whether the creditor could be guaranteed adequate protection. ${ }^{69}$

62 Id. at 236-37.

6s Id. at 231 (footnote omitted).

os Id. at 235 .

ss 17 Bankr. 515 (Bankr. C.D. Cal. 1982).

Id. at 518 .

67 Id.

${ }^{68}$ The debtor was a partnership, and the general partner had a net worth of approximately $\$ 9$ million. $I d$.

69 The difference between the outcomes in Yaffe and $B B T$ reflects a general pattern in the decisions addressing good faith: courts are usually more willing to dismiss for bad faith when the debtor is a real-estate enterprise. This can be explained by the nature of the good faith inquiry, which focuses on whether the debtor "merits" the fresh start a reorganization is thought to provide. Because real-estate enterprises typically have few employees or trade creditors, they fail to raise concerns about the impact of a liquidation on third parties. Thus, courts are probably less bothered by requiring that secured creditors of real-estate enterprises be assured the full benefit of their bargain outside of bankruptcy. Although this explains the exceptional treatment of real-estate enterprises, courts do not openly reason in this way. 
C. Substantive Effects of Bankruptcy Rules and the Collective Proceeding

Debtors sometimes seek to enter bankruptcy in order to take advantage of certain substantive rules. The issues in such cases are illustrated by the recent dispute over the legitimacy of JohnsManville's bankruptcy filing. ${ }^{70}$ This Fortune 500 corporation, with a net worth (exclusive of tort liability) of approximately $\$ 1.1$ billion at the time of filing, ${ }^{21}$ filed a chapter 11 petition alleging that its future tort liability, resulting from the manufacture of asbestos products, would exceed its net worth. The immediate problem, according to Johns-Manville, stemmed from an accounting rule requiring it to establish a reserve of at least $\$ 1.9$ billion to cover this future liability, which in turn would have triggered the acceleration of approximately $\$ 450$ million of outstanding debt, thus forcing liquidation of the company. ${ }^{22}$ Attorneys representing members of the affected class of plaintiffs moved to dismiss the petition, citing Johns-Manville's alleged "lack of good faith in filing its petition,"

30 On the Johns-Manville issue, see Phillips, Asbestos Litigation: The Test of the Tort System, 36 ARK. L. REv. 343, 356-57 (1982) (use of bankruptcy by asbestos companies "problematical"; suggests the purpose of the petition is to delay and inconvenience tort claimants); Note, Escape from Debtor's Prison: The Manville Reorganization, 48 ALB. L. REv. $1045,1056-57$ (1984) (favoring Johns-Manville's use of chapter 11 and suggesting that the "good faith" doctrine has not been violated) [hereinafter cited as Note, The Manville Reorganization]; Note, Who Will Compensate the Victims of Asbestos-Related Diseases? Manville's Chapter 11 Fuels the Fire, 14 Envth. L. 465, 466, 479-80, 487, 489-91 (1984) (Johns-Manville's filing raises the specter of other financially successful debtors using bankruptcy to limit liability; Congress should consider reforming the bankruptcy law to foreclose use of bankruptcy by solvent companies); Note, The Manville Bankruptcy: Treating Mass Tort Claims in Chapter 11 Proceedings, 96 Harv. L. Rev. 1121, 1122-28 (1983) (JohnsManville is attempting to limit the aggregate size of current and future liability through bankruptcy; this use is appropriate only where it is more likely than not that the corporation will be rendered insolvent as a result of these claims); Note, Manville: Good Faith Reorganization or "Insulated" Bankruptcy, 12 Hopstra L. REv. 121, 129-36, 150-52 (1983) (if potential tort claimants have a "claim" under the Code, Johns-Manville should be entitled to protection of the bankruptcy laws); Comment, The Manville Corporate Bankruptcy: An Abuse of the Judicial Process?, 11 Pepperdine L. Rev. 151, 184 (1983) (Johns-Manville's use of bankruptcy "dubious" but not an abuse of the law as it now stands); Comment, Relief from Tort Liability Through Reorganization, 131 U. PA. L. REv. 1227, 1238, 1247 (1983) (mere showing that Johns-Manville is currently solvent not enough to establish bad faith, but court should dismiss if there is evidence that firm does not "need" bankruptcy and instead is using it to limit its liability) [hereinafter cited as Comment, Relief from Tort Liability]; Comment, Manville Corporation and the "Good Faith" Standard for Reorganization Under the Bankruptcy Code, 14 U. ToL. L. Rev. 1467, 1468-70, 1474-1506 (1983) (arguing, on the basis of the good faith standard under both the Act and the Code, that Johns-Manville filed in bad faith).

${ }^{71}$ See Note, The Manville Reorganization, supra note 70, at 1045-46 (citing affidavits by Johns-Manville officers).

${ }^{72}$ In re Johns-Manville Corp., 36 Bankr. 727, 730 (Bankr. S.D.N.Y. 1984). 
and contending that Johns-Manville "perpetrated a fraud" on the court. ${ }^{73}$ The plaintiffs claimed that Johns-Manville entered bankruptcy in order to limit its liability to creditors, including asbestos victims. ${ }^{74}$

The issue in the Johns-Manville case, said the court, was whether "even egregious error, in overcalculation of Manville's financial problems, [is] relevant to establish the kind of bad faith in the sense of an abuse of this Court's jurisdiction which will vitiate the filing of a Chapter 11 petition." "Ts The court began by noting the absence of an insolvency requirement under the Code, ${ }^{76}$ but then added an important gloss: "the drafters of the Code envisioned that a financially beleaguered debtor with real debt and real creditors should not be required to wait until the economic situation is beyond repair in order to file a reorganization petition." While neither the language of the Code nor its legislative history authorizes an examination of the debtor's financial status, ${ }^{78}$ the court incorporated just such an inquiry into its examination of the debtor's good faith. The court stated that good faith is not a "strict and absolute . . . predicate to filing," and observed that the good faith requirement in the old Bankruptcy Act had been deleted from the Code. ${ }^{79}$ Nevertheless it is an "elastic" concept "which can be read into the statute on a limited ad hoc basis," proposition for which the court cited its own opinion in In re Eden Associates, where it had stated that "[i]n determining a lack of good faith, the court should emphasize the intent to abuse the ju-

${ }^{73}$ Id. The affected class of plaintiffs consisted of those victims who had been exposed to asbestos and had manifested symptoms of asbestos-related diseases. Given the limited pool of assets from which claims could be satisfied, the interests of this class differed from those victims who had been exposed to asbestos but who had not yet manifested any asbestos-related symptoms. The narrow bankruptcy question was whether the members of this latter group have a "claim" as that word is defined in the Code, 11 U.S.C. § 101(4) (1982). That question is beyond the scope of this comment; for a good general discussion of the issues, see Roe, Bankruptcy and Mass Tort, 84 CoLum. L. REv. 846, 892-904 (1984).

74 In re Johns-Manville Corp., 36 Bankr. 727, 730 (Bankr. S.D.N.Y. 1984).

as Id.

76 Id. at 732 .

77 Id. at 736 (emphasis added).

${ }^{78}$ See supra notes 3, 5; House Report, supra note 3, at 405, 1978 U.S. CODE Cong. \& AD. NEws at 6361 ("[Section 1112(b)] brings together all of the conversion and dismissal rules for chapter 11 cases.") (emphasis added); cf. Empire Enters. v. Koopmans (In re Koopmans), 22 Bankr. 395, 403 (Bankr. D. Utah 1982) ("[In enacting the Code, it] was necessary to coordinate the standards for dismissal with provisions for liquidation so that vestiges of prior law, such as the good faith hearing, did not resurface to complicate realization of the reform goal.").

38 Bankr. at 737.

so Id. at 737. 
dicial process rather than to delay creditors."81 The court did not explain what, other than hindering creditors in the exercise of their rights, would constitute "abuse of the judicial process."

\section{ANALYSIS}

As the preceding discussion indicates, bankruptcy courts offer no coherent rationale for a good faith requirement. This is not surprising: because the motive of a debtor in filing for bankruptcy is entirely irrelevant, such a justification cannot exist. In a collective proceeding designed to sort out creditors' rights, the sole concern of the bankruptcy court should be to distribute the estate's assets in accordance with nonbankruptcy entitlements. If this is done properly, creditors will have no need to attack the motives of a debtor in filing a bankruptcy petition. Rather, they may directly contest whether those nonbankruptcy entitlements are preserved. The transfer-of-assets and adequate-protection cases that initially gave rise to the imposition of a good faith requirement, and the recent extension of this doctrine in the Johns-Manville bankruptcy case, illustrate the way in which the good faith analysis offered by the courts obscures the real issues.

\section{A. Adequate Protection and Pre-Petition Transfers}

Section 362 of the Code imposes an automatic stay on all collection efforts by a debtor's creditors, ${ }^{82}$ thus preventing the piecemeal liquidation of the debtor. ${ }^{83}$ The stay remains in effect until either the whole petition is dismissed ${ }^{84}$ or a secured creditor demonstrates that it is not receiving "adequate protection." means of providing "adequate protection" are described in the Code ${ }^{86}$ the Code does not expressly address the question of whether such protection includes the time value of money. ${ }^{87} \mathrm{~A}$

s1 In re Eden Assocs., 13 Bankr. 578, 584 (Bankr. S.D.N.Y. 1981).

${ }^{82} 11$ U.S.C.A. \& 362 (West 1979 \& Supp. 1985).

s3 See D. BAIRD \& T. JACKSON, supra note 16, at 363 .

84 11 U.S.C.A. § 362(c)(2) (West 1979 \& Supp. 1985).

${ }^{85}$ Id. \& 362(d)(1).

${ }^{86}$ The standard is illustrated rather than defined in section $361 . I d$. $\S 361$. In order to compensate the secured creditor for the denial of its right to foreclosure, the court may order the debtor to give the secured creditor cash payments that compensate it for any decrease in the value of the creditor's interest in the property, id. $\$ 361$ (1), or additional liens compensating for the same, id. $\S 361$ (2), or any "other relief" that results in the creditor receiving the "indubitable equivalent" of its property interest, $i d$. $\$ 361(3)$.

${ }^{87}$ See Comment, Compensation for Time Value as Part of Adequate Protection During the Automatic Stay in Bankruptcy, 50 U. CHI. L. REv. 305, 307, 319 (1983). Those asserting that the Code does not require time-value compensation point to the following pas- 
compelling construction of the statute finds that Congress intended secured creditors to receive the time value of money. ${ }^{88}$ The normative justification for such a conclusion, which is provided by the creditors' bargain model, ${ }^{89}$ lays bare the problem created by imposing a good faith requirement.

In theory, secured creditors should be indifferent to the filing of a bankruptcy petition. ${ }^{80}$ Yet, in nearly every transfer and feasibility case raising the good faith issue, the party objecting to the petition is a secured creditor. ${ }^{91}$ This departure from theoretical expectations indicates that, in practice, courts are applying bankruptcy rules that diverge from the rules for which creditors would bargain. It is obvious that if the secured creditor is not indifferent

sage in the Code's legislative history:

The ... means of providing adequate protection. . . . are neither exclusive nor exhaustive. . . . It is expected that the courts will apply the concept in light of facts of each case and general equitable principles. . . . There are an infinite number of variations possible in dealings between debtors and credtors, [sic] the law is continually developing and new ideas are continually being implemented .... The flexibility is important to permit courts to adapt to varying circumstances and changing modes of financing.

House REPORT, supra note 3, at 339, 1978 U.S. CODE CoNG. \& AD. NEws at 6295, quoted in Nimmer, Secured Creditors, supra note 11, at 16-17. In contrast, those asserting that adequate protection requires time-value compensation point to the statement, made in the course of the same discussion, that "[s]ecured creditors should not be deprived of the benefit of their bargain." House REPORT, supra note 3, at 339, 1978 U.S. CodE Cong. \& AD. NEwS at 6295 . The bargain made by a secured creditor is not limited to the receipt of a sum certain (the value of the collateral), but the receipt of that sum at a certain time-specifically, when the right of foreclosure arises and the creditor could dispose of the property and reinvest the money received at prevailing market rates. See Baird \& Jackson, supra note 13, at 115, 128; Comment, supra, at 312. Because the legislative history can plausibly be read to encompass either view, it is fair to conclude that Congress left the question of what constitutes adequate protection to be decided by courts on a case-by-case basis. Recent Supreme Court decisions support the position that courts must look to nonbankruptcy entitlements to determine what rights a party to a bankruptcy proceeding has, at least where Congress has left the question to the courts. See Commodity Futures Trading Comm'n v. Weintraub, 105 S. Ct. 1986, 1992-93 (1985); Butner v. United States, 440 U.S. 48, 55 (1979). Since, outside of bankruptcy, secured creditors could foreclose on the collateral, sell it, and reinvest the proceeds at the market rate of interest, bankruptcy law should give secured creditors time-value compensation-the compensation most closely analogous to the secured creditor's nonbankruptcy entitlements. Cf. Weintraub, $105 \mathrm{~S}$. Ct. at 1293 (analogizing to nonbankruptcy law to determine whether trustee may waive corporate debtor's attorney-client privilege); Comment, supra note 25, at 1249-57 (same).

${ }^{88}$ See Comment, supra note 87.

${ }^{80}$ See supra notes 12-28 and accompanying text.

- See supra text accompanying notes 26-28.

21 See, e.g., cases cited supra notes $35,38,54 \& 57$. The few cases in which an unsecured creditor raises a good faith objection usually involve only one or two major creditors, a situation in which the collective proceeding of bankruptcy is not especially useful. See, e.g., In re Mogul, 17 Bankr. 680 (Bankr. M.D. Fla. 1982); In re Horizon Hospital, Inc., 10 Bankr. 672 (Bankr. M.D. Fla. 1981). 
to whether a bankruptcy proceeding is commenced, then the secured creditor must expect that it will be undercompensated in the bankruptcy forum. In short, although the secured creditor formulates its objections in terms of good faith, the secured creditor probably is not concerned about the debtor's motivation in filing a bankruptcy petition. The complaints of the secured creditor can only be a reflection of the reduced value it expects to receive in bankruptcy. ${ }^{92}$

Secured creditors object to bankruptcy petitions because bankruptcy courts do not grant the adequate protection required by the Code and predicted by the creditors' bargain model. Bankruptcy courts have consistently refused to grant secured creditors the time value of their investment. ${ }^{93}$ Moreover, the courts tend to overestimate the value of the secured creditor's collateral..$^{94}$ Through such overvaluation, the courts are led to assert that the collateral fully protects the secured creditor's claim when, in fact, it does not. ${ }^{95}$ These valuation problems result from the actions of courts, not of debtors; to decide the questions created by these valuation problems in terms of the debtor's good faith is to miss the point.

The failure to provide truly adequate protection to secured creditors pervades bankruptcy proceedings. ${ }^{96}$ In many instances, courts simply will not listen to the argument that the secured creditor is undercompensated for the time value of its investment. Courts recognize that there is a problem only in the extreme case

92 See Jackson, supra note 12, at 874-77.

ss See, e.g., Crocker Nat'l Bank v. American Mariner Indus. (In re American Mariner Indus.), 27 Bankr. 1004, 1009 (Bankr. 9th Cir. 1983) ("[T]here is no expression [in the Code's legislative history] of an intent to compensate the secured party for the delay in its potential to realize a profit from a more lucrative investment of the funds which could be generated from a successful sale of the collateral to a third party."), rev'd, 734 F.2d 426 (9th Cir. 1984); General Elec. Mortgage Corp. v. South Village, Inc. (In re South Village, Inc.), 25 Bankr. 987, 989-1002 (Bankr. D. Utah 1982) (adequate protection read as including timevalue compensation is inconsistent with the Code's alternative formulation of the means of providing it, the equitable case-by-case approach adopted in the legislative history, and other sections of the Code); In re Pine Lake Village Apartment Co., 19 Bankr. 819, 827 (Bankr. S.D.N.Y. 1982) ("Adequate protection relates to preservation of the collateral value, and not to compensation for the loss of a better business opportunity.").

or See Baird \& Jackson, supra note 13, at 126-27 \& n.91 (citing examples from cases); Blum, The Law and Language of Corporate Reorganizations, 17 U. CHI. L. REv. 565, 577-78 \& n.18 (1950); Jackson, supra note 12, at 874-77.

${ }^{28}$ See, e.g., In re Nite Lite Inns, 17 Bankr. 367, 373 (Bankr. S.D. Cal. 1982) (rejecting, as an "artificial and unrealistic burden on [the] debtor['s attempt] to reorganize," the creditor's contention that the note it received should reflect the $40-50 \%$ discount a bank would set in converting the note to cash).

st See Baird \& Jackson, supra note 13, at 98-99. 
where the debtor has obviously filed for bankruptcy solely to preserve the benefit, but not the responsibilities, of an earlier bargain struck with the creditor-thus obtaining a windfall at the expense of the secured creditor. ${ }^{97}$

In both the change-of-form and the transfer-of-assets cases, the lack of adequate protection is complicated by the fact that debtors are attempting to escape from the bright-line rule, provided by the Code, that determines which debtors are eligible for a collective proceeding. By confining eligible debtors to "business trusts" and the like, Congress attempted to isolate those debtors in which a large number of parties have an ownership interest and thus are likely to require a collective proceeding to sort out claims against the estate. ${ }^{98}$ Cases in which ineligible debtors attempt to make use of the bankruptcy forum demonstrate that entities outside the statutory definition of eligible debtors, like land trusts, often require collective proceedings to sort out the rights of owners. But changes of form or transfers of assets to eligible entities would not be resisted by secured creditors if courts provided the adequate protection required by the Code. In fact, creditors would desire collective proceedings for the efficiencies they create. ${ }^{99}$ When adequate protection is likely to be absent, however, and secured creditors challenge the petition, courts have analyzed the change of form or transfer of assets in terms of good faith even though the transaction itself may be beneficial in enhancing the value of the estate as a whole. ${ }^{100}$ This undesirable result can only

${ }^{97}$ See, e.g., Yaffe v. Andrews (In re Andrews), 17 Bankr. 515 (Bankr. C.D. Cal. 1982) (bad faith use of bankruptcy to preserve a low interest loan); In re Victory Constr. Co., 9 Bankr. 549 (Bankr. C.D. Cal. 1981) (same).

${ }^{98}$ See, e.g., In re Treasure Island Land Trust, 2 Bankr. 332, 334 (Bankr. M.D. Fla. 1980) ("The basic distinction between business trusts and nonbusiness trusts is that business trusts are created for the purpose of carrying on some kind of business or commercial activity for profit; the object of a nonbusiness trust is to protect and preserve the trust res."); see also In re Dreske Greenway Trust, 14 Bankr. 618, 622 (Bankr. E.D. Wis. 1981) (rejecting the creditor's contention that the debtor was an ineligible trust because the trust instruments specifically contemplated the use of the trust assets in forming and running a business).

89 See supra text accompanying notes 19-23; text following note 25 .

100 Courts have analyzed transfer and change-of-form cases under the good faith doctrine as if they were looking for "sham" transactions. This inquiry misunderstands the purpose of the eligible-debtor provisions of the Code, which is to enumerate the classes of cases in which a collective proceeding is usually necessary. Contrary to the viewpoint of the courts as evidenced by their good faith analyses, Congress's intent is not frustrated by either a change in corporate form or the transfer of assets to an eligible debtor so long as there are multiple parties claiming an ownership interest in the debtor's assets. If there are multiple parties, then bankruptcy's collective proceeding is an effective mechanism for maximizing the estate's assets. See supra notes 15-23, 33 and accompanying text. If, however, courts fail 
be caused by the legitimate fears of secured creditors.

\section{B. Extension to New Areas}

The good faith inquiry initially arose in cases where the real issue was adequate protection. Perhaps because the good faith inquiry has never been related to the underlying problem-failure to apply the requirements of the Code properly - and because the approach lacks any theoretical justification, courts have begun to apply it in other areas. In cases where courts have applied the good faith requirement to debtors that allegedly file for bankruptcy merely to take advantage of the substantive effects of bankruptcy rules, no issue of adequate protection is involved..$^{101}$ In these cases, one party seeks to invoke good faith to force dismissal of the petition because it enjoys a superior strategic position outside of bankruptcy. Again, however, by focusing on the debtor's motive, courts have missed the core issue: whether there exists a real need for a collective proceeding or whether, on the contrary, a party is attempting to take advantage of a more attractive bankruptcy rule. ${ }^{102}$

to provide secured creditors with time-value compensation, debtors will have an incentive to enter bankruptcy in order to take advantage of the more favorable bankruptcy rule-a rule that transfers wealth from secured creditor to debtor by allowing the debtor to continue to use the assets interest free. See supra note 28. This strategic behavior is a reflection of the perverse incentives created by the courts' failure to give secured creditors the time value of their investments; the courts' good faith analysis of the debtor's transaction fails to confront this problem.

101 In cases like Johns-Manville, creditors have raised good faith challenges based upon allegations that the debtor has filed a petition not to take advantage of the efficiencies provided by bankruptcy's collective proceeding but rather to take advantage of a change in substantive rights in bankruptcy from the nonbankruptcy norm. In this sense, the adequateprotection cases and cases like Johns-Manville share a common characteristic: both groups of cases result from what debtors perceive as more advantageous substantive rights in bankruptcy. The point of distinction between the two groups of cases is that the adequate protection problem stems from the improper implementation of bankruptcy rules, while cases like Johns-Manville result from changes in substantive rights needed to bring about a collective proceeding. The appropriate inquiry in cases like Johns-Manville is whether the owners of the corporation will benefit from a collective proceeding. If not, the petition should be dismissed. If the owners will not benefit from a collective proceeding, the most likely motivation for the filing is to take advantage of a change in substantive rights. Nonetheless, the inquiry as to whether the debtor is in need of a collective proceeding is an objective one; it does not turn on the actual motives of the debtor. The good faith inquiry relies precisely upon this factor.

${ }_{102}$ Another example of the problem is the alleged abuse of bankruptcy to reject collective-bargaining agreements. Prior to the adoption of 11 U.S.C.A. § 1113 (West Supp. 1985), labor unions commonly complained that employers had entered bankruptcy solely in order to use the power under section 365(a) to reject collective-bargaining agreements as executory contracts. See, e.g., Local Union 20 v. Brada Miller Freight Sys., Inc. (In re Brada 
In Johns-Manville, for example, the petition demonstrated a need for a collective proceeding. The company's future liability (discounted to present value) clearly exceeded the value of its assets, and the company had a multitude of investors. ${ }^{103}$ Absent a bankruptcy petition, individual creditors would have obtained execution judgments against Johns-Manville, eventually forcing the piecemeal liquidation of the company. ${ }^{104}$ The very purpose of a bankruptcy reorganization is to prevent such results. The real reason behind the good faith objection was the nature of the company's future liabilities. Most of these liabilities were in the form of potential claims by those persons who had been exposed to asbestos but were not yet aware that they had contracted asbestosis. ${ }^{105}$ Inside a collective proceeding, the interests of these contingent creditors must be taken into account. ${ }^{106}$ Outside of bankruptcy, however, tort claimants with known present injuries have a strategic advantage over other potential claimants: they can pursue their claims first and have them satisfied in full. Instead of confronting this strategic behavior, the court engaged in the unhelpful good faith analysis.

The issue was not whether Johns-Manville had "real" debts and whether the bankruptcy court should apply its ad hoc good faith test, but rather whether the company's financial difficulties were so severe that a collective proceeding would have been in the best interests of all of Johns-Manville's creditors. Moreover, even under the courts' own good faith inquiry, it is difficult to understand how the company could have filed for bankruptcy in "bad faith": Johns-Manville's equityholders would not receive anything more within the bankruptcy forum than they would have received outside of bankruptcy unless the bankruptcy court undervalued the claims of creditors, including future tort claimants. ${ }^{107}$ Even if

Miller Freight Sys., Inc.), 702 F.2d 890, 901 (11th Cir. 1983); In re Continental Airlines Corp., 38 Bankr. 67, 71 (Bankr. S.D. Tex. 1984); In re Braniff Airways, Inc., 25 Bankr. 216, 218 (Bankr. N.D. Tex. 1982). In NLRB v. Bildisco, 104 S. Ct. 1188, 1196 (1984), the Supreme Court resolved the issue by permitting rejection of such contracts under a "burdensome to the estate" standard, and Congress essentially codified this standard in section 1113. Here, in stark contrast to other areas in which the good faith problem has arisen, a rather open-ended, equitable inquiry has been expressly authorized by Congress and is required by the inherent tension between national labor policy and the bankruptcy system.

${ }_{103}$ In re Johns-Manville Corp., 36 Bankr. 727, 730 (Bankr. S.D.N.Y. 1984).

${ }^{104} I d$. at 730,740 .

10 Id. at 740 .

${ }^{108}$ See D. Baird \& T. JAckson, supra note 16, at 219-22.

${ }^{107}$ Cf. Note, The Manville Reorganization, supra note 70, at 1070-71 ("If the asbestos claimants' unsecured debt is valued in astronomical amounts, management must accept confirmation of a plan that cancels the interests of present shareholders, something it certainly 
the prospects of undervaluation prompted Johns-Manville to file for bankruptcy, the good faith inquiry is useless in resolving the underlying valuation issue.

\section{CONCLUSION}

Courts and commentators have eagerly embraced a good faith requirement under current bankruptcy law despite the fact that a similar requirement was deliberately eliminated from the old Bankruptcy Act. Unfortunately, proponents of a good faith requirement have failed to consider the appropriateness of such a requirement in light of the normative framework of bankruptcy. The use of an ambiguous equitable doctrine avoids the harder and more important issues: the proper definition of "adequate protection" and the appropriate uses of bankruptcy as a collective proceeding. Courts should abandon the good faith doctrine and face up to the real problems it obscures.

Daniel J. Tyukody, Jr.

will not do placidly. . . . A necessary query follows: why then is Manville invoking Chapter 11?"); Roe, supra note 73, at 863 ("There is . . . a biblical irony in the result to which we are driven if we combine the principles of debtor rehabilitation, equality among creditors (including tort claimants), and priority of creditors (including tort claimants) over owners. Telescoping future claims into an early reorganization makes the mass tort victims of a firm's misdeeds the firm's owners."). 